\title{
Practical knowledge in preparing financial statements and ICT-enabled financial plans: An empirical study among entrepreneurial students in Oman
}

\author{
Mohammed Muneerali Thottoli
}

\begin{abstract}
A B S T R A C T
Objective: This paper aims to examine practical knowledge in preparing financial statements (FStts), practical knowledge in information and communication technology (ICT) and ICT-enabled financial plan (ICTeFP) among entrepreneurial students within Universities in Oman.

Research Design \& Methods: Primary data were collected from university students to analyze practical knowledge in preparing FStts and related ICT skills. Items of FStts were considered to measure entrepreneurial students' practical knowledge to prepare FStts. Besides, entrepreneurial students' skills in basic Microsoft tools have also been considered.

Findings: The findings were evaluated by applying structural equation modelling-partial least squares (SEMPLS). The findings of the current study reveal that entrepreneurial students' practical knowledge in preparing FStts is lacking whereas it shows that the students possess adequate basic skills in ICT. Thus, automated ICTeFP can be useful in managing entrepreneurship creativity and innovation course more effectively.

Implications \& Recommendations: The findings suggest that ICTeFP is an excellent contribution to enrich the recently compulsory course, (both for accounting and non-accounting students), entrepreneurship creativity, and innovation.
\end{abstract}

Contribution \& Value Added: The study solely for the entrepreneurial students who are studying the course, entrepreneurship creativity and innovation, in Oman. The research is one of the first to empirically analyze the relationship between practical knowledge in preparing FStts, practical knowledge in ICT, and ICTeFP among entrepreneurial students within universities in Oman.

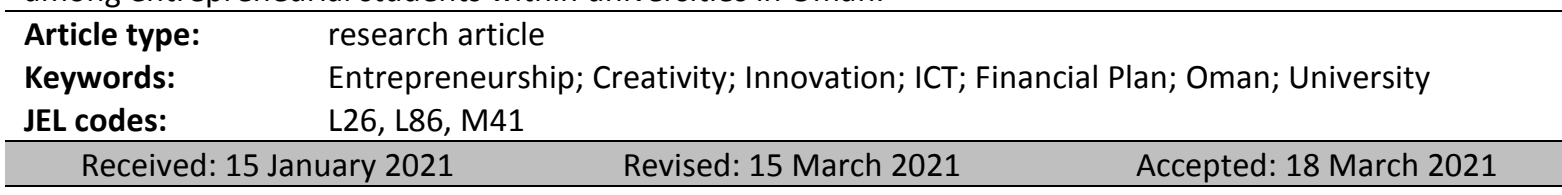

\section{Suggested citation:}

Thottoli, M.M. (2021). Practical knowledge in preparing financial statements and ICT-enabled financial plans: An empirical study among entrepreneurial students in Oman. International Entrepreneurship Review, 7(1), 2131. https://doi.org/10.15678/ IER.2021.0701.02

\section{INTRODUCTION}

Young aspirant entrepreneurs should know that information technology (IT) or broader information and communication technology (ICT) enabled financial plans for their innovative business idea is an essential element for success. Systematic preparation of business' financial planning extends the entrepreneurial students to understand the financial feasibility of their proposed venture. A well-designed automated financial planning facilitates students to ascertain their intended business financial goals, such as short-term and long-term, and create a flexible financial budget to know various possible payback periods. Cost control, tax planning, and fair financial statements (FStts) will help entrepreneurial students with proper planning on their identified working capital. An ICT-based or ICT-enabled financial plan (ICTeFP) facilitates the estimation of venture capital, seed capital, and working capital 
requirements in different combinations. ICT enables to use of predefined financial templates which can help beginners or non-accounting students to present their innovative business ideas' financials more quickly. An ICTeFP is useful to automate budgeting, analyzing, and forecasting the data that facilitates to assist the planned business' financial health and assist in predicting alternative financial strategy and financial impact. ICT-enabled financial tools heavily to depend on statistical assessment. The technology-enabled tool might be able to evaluate the intended business idea of potential entrepreneurs. The proposed automated software will assess business plans based on earlier data, business statistics, economic environment along related qualitative data. ICT-enabled software recommends improvements in the financial plan, recommendations on seed capital. Machine learning helps to upload past financial data to the software (Mavlutova et al., 2020). ICT-enabled entrepreneurial education will gradually affect both classroom-based training or teaching, but more precisely it leads to an innovative way to deliver entrepreneurship courses (Sousa et al., 2019).

However, higher education institutions were facing challenges to deliver entrepreneurship courses (Mavlutova et al., 2020). Knowledge in preparing FStts is considered an essential factor in adopting ICT-enabled entrepreneurship (Byun, Sung, Park, \& Choi, 2018). Lack of support, less innovation in ICTeFP, and lack of practical knowledge in their academic in terms of accounting and business are some obstacles that challenge the adoption of e-entrepreneurship for e-startups (Islam \& Alghobiri, 2018)

Students even though their major accounting, have less knowledge on various sections included in a financial plan; some of them don't know how to prepare income statements, statements of financial position, cash flow statement, and equity shareholder's statement.

Recently, in the Gulf Cooperation Council (GCC), entrepreneurship education considers special importance. Entrepreneurship education among students has received increased awareness in Oman. Now in Oman, the course, Entrepreneurship Creativity, and Innovation have been made compulsory for all the students who are diploma or bachelor irrespective of their major (accounting / non-accounting).

Technical and Vocational Education Training Strategy provides Oman to boost entrepreneurship education at the state level. The government has taken initiatives to include compulsory entrepreneurship creativity and innovation course with a practical section in the current curriculum development. The main aim of the program is to promote entrepreneurship, innovation, and to provide entrepreneurship creativity education, particularly among Omani students. Oman has considered this may enhance a mechanism for economic growth.

The above-listed challenges need attention for researchers to practical knowledge in preparing FStts, practical knowledge in ICT, and ICTeFP among entrepreneurial students within universities in Oman. Thus, this paper aims to examine practical knowledge in preparing FStts, practical knowledge in ICT, and ICTeFP among entrepreneurial students within Universities in Oman.

The following section provides a review of the literature, methodology, results, discussions, and conclusions of the study.

\section{LITERATURE REVIEW AND HYPOTHESES DEVELOPMENT}

\section{An ICT-enabled financial plan}

An information and communication technology-enabled financial plan is a software that supports, enhances, optimize, and integrates financial aspects of the proposed business plan that provides automation of FStts with details of budgeting, payback period, ratio analysis. An innovative approach to entrepreneurial education and training through automated software has been required to test and improve the feasibility of students' innovative business ideas (Mavlutova et al., 2020). The roles of ICT enabled entrepreneurial education and entrepreneurship development were examined by (Sulaiman et al., 2020). The impacts of technology-enabled practical entrepreneurship teaching methods and students' entrepreneurial attitudes and intentions towards risk were examined by (Bandera et al., 2018), and compare with entrepreneurship courses, students' majors, knowledge of ICT, and connections with business incubator were analyzed. Information technology-enabled tools facilitated interaction between students with entrepreneurial skills acquisition and improved entrepreneurial potential (Wu et al., 2019). For promoting innovative ideas of business among non-accounting students have recommended entrepreneur- 
ial software for their entrepreneurship courses (Buffardi, 2018). The entrepreneur-support standard model had facilitated to increase entrepreneurial performance by giving level and custom-made support substances to entrepreneurs preparing for their intended business. Through this ICTeFP possibly initiate a new start-up from the university which will lead to a future successful start-up company (Shin et al., 2018). Automation attracted aspirant entrepreneurs to better convey their innovative business ideas well-thought-out way. It reveals that students who develop business ideas were ready to adopt ICTeFP for delivering their innovative business ideas (Wu et al., 2018).

\section{Practical knowledge in preparing FStts}

The students' knowledge in preparation of FStts, financial accounting practices, and classification ledger accounts were examined by (Faccia \& Mosco, 2019). Undergraduate students' understanding of accounting concepts and their practical knowledge from their first accounting class were studied by (Abbott \& Palatnik, 2018). Accounting students' attitude to entrepreneurship course, entrepreneurial skills development was studied by (Reyad et al., 2019). The level of non-accounting major students' knowledge on accounting through the establishment of automated Simplified Accounting Template for Apprentice in teaching was studied and found that it can assist the students to prepare FStts (Shamsudin et al., 2020). Teaching accounting concepts were insipid and tough to understand mainly for non-accounting major students. Entrepreneurship and accounting skills shall be used in learning through board games (Rosli et al., 2019). Technology tools integrate financial transactions with technological facilities. It speed-up accounting records, builds a more secure business environment, and lowering human mistakes. It facilitates doing accounting work timely. In the current digital world, where technologies take over time-consuming, repetitive, and redundant jobs, giving accounting professionals extra time to consider the higher level and extra productive analysis (Moşteanu \& Faccia, 2020). Knowledge in FStt preparation led to high intention on entrepreneurship education among undergraduates accounting students (Ahmad et al., 2019). If instructors want to enhance the skills, efficiency, and concept of accounting education focused on developing entrepreneurial skills, university curricula or programs should be designed innovatively by including ICT for non-business major students (Boldureanu et al., 2020).

\section{Practical knowledge in ICT}

Universities or colleges play a key role in the advancement of proficiency in ICT that equips their entrepreneurial graduate students to enter the labor market and produce new job opportunities choices through entrepreneurship that contributes to the solution of main international problems (Portuguez Castro \& Gómez Zermeño, 2020). The personality traits of university students and how such traits influence their IT education were studied by (Al-Qirim et al., 2018). MS Office and technology-based learning were decided by apparent usefulness. Students' frequent use of MS Office might be considered by educational institutions to aim their efforts on developing certain aspects of the platforms that would lead to greater levels of student interactions with technology. This will lead to greater levels of academic success as students engaged more by use of advanced MS Office skills apply using technology (Venter \& Swart, 2018). IT skills are ever more cited as both workplace and curriculum weaknesses in accounting education. Employers and educators believe that MS Excel skills are considered as one of the technical competencies necessary for junior accountants. These IT skills developments embark on requiring MS Office Excel certification should include in some entry-level accounting curriculum (Rotondo, 2020). Microsoft Excel with Visual Basic for Application provides the students to draw graphs much interactive by diversified models. MS Excel facilitates economical, time effectiveness, easy find option, enhanced students' insight of accounting concepts, and nurture students' sense of confidence (Bernard et al., 2018). Microsoft Excel is the best commonly used IT tool, the best crucial IT tool for fresh hires, and more importantly, MS Excel has been emphasized in colleges and universities' accounting curricula. MS Excel is reliable among different branches of accounting such as audit, FStts, and tax across all other related experience levels. Further, PowerPoint, MS word, enterprise resource planning software, and the codes of accounting standard board were found as often utilized across several areas of accounting (Lee et al., 2018). 


\section{Research questions and hypotheses}

This study will answer two research questions steered by the study as mentioned below:

RQ1: Does practical knowledge in preparing FStts influence ICTeFP?

RQ2: Does practical knowledge in ICT influence ICTeFP?

In essence, the present research study seeks to measure the degree of practical knowledge in preparing FStts, practical knowledge in ICT, and ICTeFP among entrepreneurial students within Universities in Oman. Thus, the hypotheses made in the current study are as follows:

H1: Lack of practical knowledge in preparing FStts associates with ICTeFP.

H2: Increased practical knowledge in information and communication technology associates with ICTeFP.

Consequently, the below depicted theoretical framework has been formed. The relationship among lack of practical knowledge in preparing FStts and statement and increased practical knowledge in ICT with ICTeFP is shown in the below figure (Figure 1).

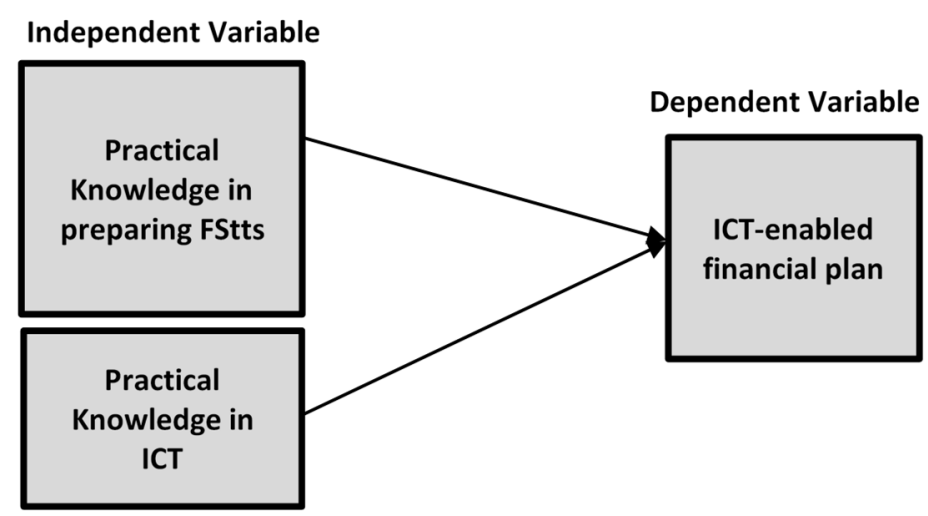

Figure 1. Theoretical Model

Source: own elaboration based on the hypothesis development.

\section{RESEARCH METHODOLOGY}

This current study has considered constructing and build a quantitative approach to assess a set of variables. The research questionnaire has employed a set of four instrument elements with a five-point Likert type scale/items to evaluate the defined variables. Some demographics comprised in this study have been based on demographic impact on students who study the compulsory course, entrepreneurship creativity, and innovation. Primary data were collected from University students to analyze practical knowledge in preparing FStts and related ICT skills. Items of FStts were considered to measure entrepreneurial students' practical knowledge to prepare FStts. Besides, entrepreneurial students' skills in basic Microsoft tools have also been considered. This study has employed a set of four instrument items comprising questionnaires with a 5-point Likert type scale/items to evaluate the variables in the present study. A cross-sectional survey was conducted at various universities and colleges in Oman during the year 2020, comprising 174 students who are registered under various majors. The findings were evaluated by applying Structural Equation Modelling-Partial Least Squares (SEM-PLS).

\section{Reliability and Validity}

The initial part of the analysis consists of the factor loading, composite reliability, Cronbach alpha, and average variance extracted (AVE). Factor loading must be higher than 0.5 (Hair et al., 2010). The AVE must be higher than or equal to 0.5 that accomplishes the internal consistency. The rule of thumb for deciding the value, alpha is; if the score " $\alpha>0.9$ - Excellent, if it is $\alpha<0.8$ - then Good, and if the $\alpha<0.7$ - considered as Acceptable (Sijtsma, 2009). Table 1 shows the reliability and validity of the variables used in the current study. 
Table 1. Reliability and Validity

\begin{tabular}{|l|c|c|c|c|}
\hline \multicolumn{1}{|c|}{ Variables } & Cronbach's Alpha & rho_A & $\begin{array}{c}\text { Composite } \\
\text { Reliability }\end{array}$ & $\begin{array}{c}\text { Average Variance } \\
\text { Extracted (AVE) }\end{array}$ \\
\hline ICTeFP & 0.940 & 0.943 & 0.951 & 0.737 \\
\hline PK in preparing FStts & 0.975 & 0.977 & 0.977 & 0.719 \\
\hline PK in ICT & 0.884 & 0.889 & 0.928 & 0.812 \\
\hline
\end{tabular}

Source: own elaboration based on the results of PLS analysis.

\section{RESULTS}

\section{Descriptive Statistics}

The results of descriptive statistics have shown in Table 2 . The dependent variable, ICTeFP, indicates that the level of practical knowledge in drafting entrepreneurial ICTeFP averaged 20\%, along with a standard deviation of 0.69 , minimum $7 \%$, and maximum of $35 \%$. Further, the determinants of practical knowledge in preparing FStts has an average of $51 \%$, along with a standard deviation of 0.16 , minimum of $17 \%$, and a maximum of $85 \%$; and the determinants of practical knowledge in ICT (PK in ICT) has an average of $10 \%$, along with standard deviation of 0.03 , minimum of $4 \%$, and a maximum of $18 \%$.

Table 2. Descriptive Statistics

\begin{tabular}{|l|c|c|c|c|}
\hline \multicolumn{1}{|c|}{ Variables } & Mean & Std. Dev & Minimum & Maximum \\
\hline ICTeFP & 0.20 & 0.69 & 0.07 & 0.35 \\
\hline PK in preparing FStts & 0.51 & 0.16 & 0.17 & 0.85 \\
\hline PK in ICT & 0.10 & 0.03 & 0.04 & 0.18 \\
\hline
\end{tabular}

Source: own elaboration based on the results of PLS analysis.

The results of the discriminant validity construct have shown in Table 3. The discriminant validity calculates the extent to which the measures of various concepts are distinct. Apart from factor loadings, this research study has examined how properly the items described the latent variable by analyzing the average variance extracted (AVE) indicator. This study's correlations values between the variables shows smaller as compared to square-root averages (AVEs). In Table 3 such values are typed in bold. The AVE is included to ascertain the validity of a variable or to evaluate convergent validity (Chin, 1998; Hulland, 1999; Vandenbosch, 1999).

Table 3. Discriminant Validity Constructs

\begin{tabular}{|l|r|r|r|}
\hline \multicolumn{1}{|c|}{ Variables } & ICT_FP & PK_Fsst & \multicolumn{1}{c|}{ PK_ICT } \\
\hline ICT_FP & $\mathbf{0 . 8 5 9}$ & & \\
\hline PK_Fsst & 0.846 & $\mathbf{0 . 8 4 8}$ & \\
\hline PK_ICT & 0.706 & 0.767 & $\mathbf{0 . 9 0 1}$ \\
\hline
\end{tabular}

Source: own elaboration based on the results of PLS analysis.

Besides of hypotheses test, the analysis was also revealing the variance explained (R2) in the endogenous variables. The R2 is in the present study shows 0.724 (Table 4) which is a substantial value agreeing by Chin (1998). It specifies that all the two exogenous variables analyzed in the study, such as practical knowledge in preparing FStts and practical knowledge in ICT support, and explains $72.4 \%$ variance independent variable, ICTeFP.

Table 4. Variance Explained

\begin{tabular}{|c|c|}
\hline Endogenous Construct & Variance Explained $\left(\mathbf{R}^{\mathbf{2}}\right)$ \\
\hline Exogenous Variables -> Endogenous (ICTeFP) & 0.724 \\
\hline
\end{tabular}

Source: own elaboration based on the results of PLS analysis. 


\section{Hypotheses Testing}

Both the hypotheses $\mathrm{H} 1$ and $\mathrm{H} 2$ were expected to have either positively or negatively correlated with practical knowledge in preparing FStts, practical knowledge in ICT, and ICTeFP (Table 5). SEMPLS employing bootstrapping methods were used for analyzing variables in the current study. The hypotheses and the structural model were analyzed to ascertain the significance of the path coefficients ( $\beta$ ) with 5,000 iterations took for execution (Chin et al., 2008). Range of the path coefficient acceptable if it is higher than 0.1 (Henseler et al., 2016). The results of the path coefficient have shown in Table 5 and Figure 2, below, shows the results of the structural model analysis. All the factors, practical knowledge in preparing FStts and practical knowledge in ICT, have positive significant relation with ICTeFP. It shows that practical knowledge in preparing FStts (path coefficient value $0.000, p<0.001$ ) has a significant influence on ICTeFP. The result also reveals practical knowledge in ICT (path coefficient value $0.006, p<0.01$ ) has a significant influence on ICTeFP.

Table 5. Path Coefficients

\begin{tabular}{|c|l|c|c|c|}
\hline Hypotheses & \multicolumn{1}{|c|}{ Path } & Path Coefficient & Standard Error & t-value \\
\hline H1 & PK Fstt -> ICT FP & 0.000 & 0.040 & $* * * 18.435$ \\
\hline H2 & PK ICT -> ICT FP & 0.006 & 0.050 & $* * 2.776$ \\
\hline
\end{tabular}

Note: Significance levels: ${ }^{* * *} \mathrm{p}<0.001$ ( $\mathrm{t}>3.33$ ), $* * \mathrm{p}<0.01$ ( $\left.\mathrm{t}>2.33\right),{ }^{*} \mathrm{p}<0.05$ ( $\left.\mathrm{t}>1.605\right)$ (based in one-tailed test).

Source: own elaboration based on the results of PLS analysis.

\section{RESULTS AND DISCUSSION}

\section{Lack of practical knowledge in preparing FSttswith ICTeFP}

The first independent variable has taken as, students' practical knowledge in preparing FStts. Numerous studies were found that there was a lack of practical knowledge in preparing FStts among accounting as well as non-accounting major students (Junger da Silva et al., 2020; Hao-Yang et al., 2018; Jie, 2017). This could be overwhelmed by adopting ICT-enabled income statements (Zheng, 2020). Lack of practical knowledge in preparing FStts among (accounting as well as non-accounting major) students was obvious and faces significant constraints to complete their compulsory course, entrepreneurship creativity, and innovation. Technology integrated financial plans are much feasible for young and aspirant entrepreneurs to realize the financial feasibility of their future innovative projects (Reyad et al., 2019). Entrepreneurship education through ICT-enabled software is much better. Adoption of technology improves course learning outcomes, students' attitude toward their innovative business start-ups, considered as the main goal of entrepreneurship and accounting education (Bandera et al., 2018; Thottoli et al., 2019b).

The above-depicted Table 5, Path Coefficients, results express positively and significantly related the link between lack of practical knowledge in preparing FStts with ICTeFP $(\beta=0.000, p<$ 0.001 ). Thus, the first hypotheses tested in the current study were supported. Meaning that some of the students in the universities were agreeing to adopt ICTeFP for their successful completion of the compulsory course, entrepreneurship creativity, and innovation. Thus, the hypothesis result conveys a strong and positive relationship between lack of practical knowledge in preparing FStts with ICTeFP. Hence, undergraduate students irrespective of their major were all agrees to prepare as well as understand different alternative feasibility reports for their anticipated innovative business plan by using automated ICTeFP. Accordingly, the cogent justification for achieving this outcome for the first hypothesis, is that entrepreneurial students' lack in knowledge of preparing FStt will upsurge the readiness to integrate ICTeFP by universities for the students' compulsory course, Entrepreneurship Creativity and Innovation. 


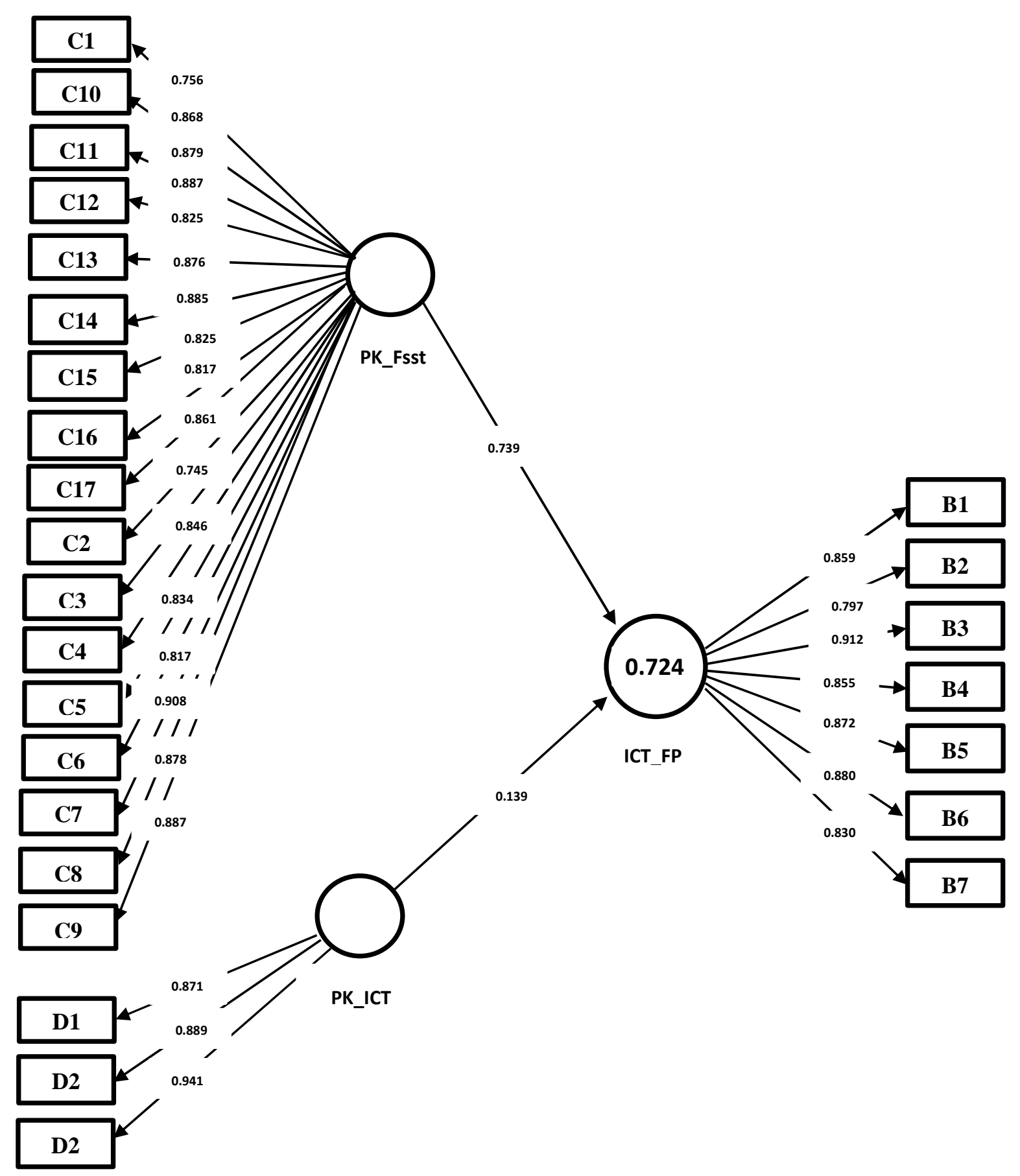

Figure 2. Structural model assessment

Source: own elaboration based on the results of PLS analysis.

\section{Practical knowledge in Information Communication Technology with ICTeFP}

The second and final independent variable has taken as, students' practical knowledge in ICT. Numerous studies were found that the majority of university students have adequate 'basic' knowledge in Microsoft office tools among accounting as well as non-accounting major students (Lee et al., 2018; Thottoli, 2020a;). Basic knowledge in ICT has sufficient to use any accounting software including ICTeFP (Thottoli et al., 2019a; Thottoli, 2020b). Adequate practical knowledge in ICT among (accounting as well as non-accounting major) students was obvious and has been considered as an added advantage for successfully use of ICTeFP to prepare automated FStts, payback period, equilibrium point, and flexible budget for their compulsory course, entrepreneurship creativity, and innovation. One may not 
necessarily be professional in ICT to understand the ever-rising influence of ICT software applications in organizations. Consequently, certainly assumed that every person holds basic information technology skills and knows how to use simple IT applications. Particularly college and university undergraduates, who are deemed to be "IT natives" and who have had sufficient practical experience to a variety of IT software package and practical training, are often considered to be a consistent cluster with more similar basic IT practical skills and very high regular ICT practice (Verhoeven et al., 2020). The level of technical competency among university students has a significant impact on ICT software applications in the day-to-day activities of students. Considerable distinctions among first-year university graduate students have observed software skills differ among countries (Eger et al., 2018; Thottoli et al., 2019c; Thottoli, 2021; Thottoli \& Thomas, 2020).

The above-depicted Table 5, Path Coefficients, results express positively and significantly related the link between practical knowledge in ICT with ICTeFP $(\beta=0.006, p<0.01)$. Thus, the second and final hypotheses tested in the current study were supported. Meaning that majority of students in the universities has increased 'basic' practical knowledge in ICT which will help to adopt ICTeFP for their compulsory course, entrepreneurship creativity, and innovation. Therefore, the second hypothesis result conveys a strong and positive relationship between increased practical knowledge in ICT with ICTeFP. Hence, undergraduate students irrespective of their major were all agrees to adopt automated handy ICTeFP to prepare as well as understand different alternative feasibility reports for their proposed innovative business plan. Accordingly, the cogent justification for achieving this outcome for the second and final hypothesis, is that entrepreneurial students have increased basic practical knowledge in the use of ICT (Microsoft office tool) and will motivate and ready to integrate ICTeFP by universities for the students' compulsory course, Entrepreneurship Creativity, and Innovation.

\section{CONCLUSIONS}

This research study offers an explanation to practical solutions among accounting and non-accounting entrepreneurial students for their compulsory course, entrepreneurship creativity, and innovation, using automated ICTeFP. It ensures that fair presentation and budgeting of financial data for their innovative business ideas. This study may be helpful for Higher Educational Institutions to revitalize University curricula by including automated ICTeFP. The research is one of the first to empirically analyze the relationship between practical knowledge in preparing FStts, practical knowledge in ICT, and ICTeFP among entrepreneurial students within Universities in Oman. The findings of the current study reveal that entrepreneurial students' practical knowledge in preparing FStts is lacking whereas it shows that the students possess adequate basic skills in ICT. Automated ICTeFP can be useful in managing entrepreneurship creativity and innovation course more effectively. The findings suggest that ICTeFP is an excellent contribution to enrich the recently compulsory course, (both for accounting and nonaccounting students), entrepreneurship creativity, and innovation.

The study solely for the entrepreneurial students who are studying the course, entrepreneurship creativity and innovation, in Oman. In the future, the study can be extended to know the requirements of implementing ICT-enabled business plans throughout Universities in other states as well.

\section{REFERENCES}

Abbott, J.I., \& Palatnik, B. R. (2018). Students' perceptions of their first accounting class: implications for instructors. Accounting Education, 27(1), 72-93. https://doi.org/10.1080/09639284.2017.1381032

Ahmad, N.L., Yusof, R., Ahmad, A. S., \& Ismail, R. (2019). The Importance of Financial Literacy towards Entrepreneurship Intention among University Students. International Journal of Academic Research in Business \& Social Science, 9(9), 18-39. DOI:10.6007/ijarbss/v9-i9/6266

Al-Qirim, N., Rouibah, K., Tarhini, A., Serhani, M. A., Yammahi, A. R., \& Yammahi, M. A. (2018). Towards a personality understanding of information technology students and their IT learning in UAE university. Education and Information Technologies, 23(1), 29-40. https://doi.org/10.1007/s10639-017-9578-1 
Bandera, C., Collins, R., \& Passerini, K. (2018). Risky business: Experiential learning, information and communications technology, and risk-taking attitudes in entrepreneurship education. The International Journal of Management Education, 16(2), 224-238. https://doi.org/10.1016/j.ijme.2018.02.006

Bernard, M., Minarti, E.D., \& Hutajulu, M. (2018). Constructing Student's Mathematical Understanding Skills and Self Confidence: Math Game with Visual Basic Application for Microsoft Excel in Learning Phytagoras at Junior High School. International Journal of Engineering \& Technology, 7(2), 732-736.

Boldureanu, G., lonescu, A.M., Bercu, A. M., Bedrule-Grigoruță, M. V., \& Boldureanu, D. (2020). Entrepreneurship education through successful entrepreneurial models in higher education institutions. Sustainability, 12(3), 1267. https://doi.org/10.3390/su12031267

Buffardi, K. (2018). Tech startup learning activities: A formative evaluation. In 2018 IEEE/ACM International Workshop on Software Engineering Education for Millennials (SEEM) (pp. 24-31). IEEE. 5.00 https://doi.org/10.1145/3194779.3194781

Byun, C.G., Sung, C.S., Park, J. Y., \& Choi, D.S. (2018). A study on the effectiveness of entrepreneurship education programs in higher education institutions: A case study of Korean graduate programs. Journal of Open Innovation: Technology, Market, and Complexity, 4(3), 26. https://doi.org/10.3390/joitmc4030026

Chin, W.W. (1998). The partial least squares approach for structural equation modeling. In G.A. Marcoulides (Ed.), Modern Methods for Business Research (pp. 295-336). Lawrence Erlbaum.

Chin, W.W., \& Peterson, R.R., \& Brown, S.S.P. (2008). Structural equation modeling in marketing: Some practical reminders. The Journal of Marketing Theory and Practice, 16(4), 287-298. https://doi.org/10.2753/MTP1069-6679160402

Junger da Silva, R., Tommasetti, R., Zaidan Gomes, M. \& da Silva Macedo, M.Á. (2020). How green is accounting? Brazilian students' perception. International Journal of Sustainability in Higher Education, 21(2), 228-243. https://doi.org/10.1108/IJSHE-07-2019-0232

Eger, L., Klement, M., Pisoňová, M., \& Petrová, G. (2018). Different user groups of university students and their ict competence: evidence from three countries in central Europe. Journal of Baltic Science Education, 17(5), 851.

Faccia, A., \& Mosco, D. (2019). Understanding the Nature of Accounts Using Comprehensive Tools to Understand Financial Statements. Retrieved February 21, 2021 from https://essuir.sumdu.edu.ua/handle/123456789/75516. http://doi.org/10.21272/fmir.3(3).18-27.2019.

Hair, J. F., Black, W. C., Babin, B. J., Anderson, R. E., \& Tatham, R. L. (2010). Cluster Analysis. Multivariate data analysis. Volume 7th ed. Edited by: Hair JF.

Hao-Yang, W.U., Xing-Chen, W.A.N.G., \& Yue, L E.N.G. (2018). Analysis of Reform Thinking and Countermeasure for Higher Education for Accounting in New Normal. DEStech Transactions on Economics, Business and Management, (eced). 10.12783/dtem/eced2018/23985

Henseler, J., Hubona, G. \& Ray, P.A. (2016), “Using PLS path modeling in new technology research: updated guidelines", Industrial Management \& Data Systems, Vol. 116 No. 1, pp. 2-20. https://doi.org/10.1108/IMDS09-2015-0382

Hulland, J. (1999). Use of partial least squares (PLS) in strategic management research: a review of four recent studies. Strategic Management Journal, 20(2), 195-204. https://doi.org/10.1002/(SICI)10970266(199902)20:2<195::AID-SMJ13>3.0.CO;2-7

Islam, M.A., \& Alghobiri, M.A. (2018). E-Entrepreneurship for E-Startups: Potentials, Common Challenges and Way Forward. Information Management and Business Review, 10(4), 44-50. https://ssrn.com/abstract $=3319753$

Jie, Z. (2017). Research on Practical Teaching System Of Applied Accounting Major. In 2017 2nd International Conference on Education, Sports, Arts and Management Engineering (ICESAME 2017) (pp. 1166-1169). Atlantis Press. https://doi.org/10.2991/icesame-17.2017.254

Lee, L., Kerler, W., \& Ivancevich, D. (2018). Beyond Excel: Software Tools and the Accounting Curriculum. AIS Educator Journal, 13(1), 44-61. https://doi.org/10.3194/1935-8156-13.1.44

Mavlutova, I., Lesinskis, K., Liogys, M., \&Hermanis, J. (2020). Innovative teaching techniques for entrepreneurship education in the era of digitalisation. WSEAS Transactions on Environment and Development, 725-733. DOI: 10.37394/232015.2020.16.75

Moşteanu, N. R., \& Faccia, A. (2020). Digital Systems and New Challenges of Financial Management-FinTech, XBRL, Blockchain and Cryptocurrencies. Quality-Access to Success Journal, 21(174), 159-166. 
Portuguez Castro, M., \& Gómez Zermeño, M. G. (2020). Educational Innovation Supported by ICT to Identify Entrepreneurial Skills in Students in Higher Education. Retrieved Feb 21, 2021 from https://www.researchgate.net/profile/May_Portuguez_Castro/publication/345034915_Educational_Innovation_Supported_by_ICT_to_Identify_Entrepreneurial_Skills_in_Students_in_Higher_Education/links/5f9c8383a6fdccfd7b8de17c/Educational-Innovation-Supported-by-ICT-to-Identify-Entrepreneurial-Skills-in-Students-in-Higher-Education.pdf.

Reyad, S.M.R., Musleh Al-Sartawi, A., Badawi, S. and Hamdan, A. (2019), "Do entrepreneurial skills affect entrepreneurship attitudes in accounting education?", Higher Education, Skills and Work-Based Learning, Vol. 9 No. 4, pp. 739-757. https://doi.org/10.1108/HESWBL-01-2019-0013

Rosli, K., Khairudin, N., \& Saat, R.M. (2019). Gamification in Entrepreneurship and Accounting Education. Academy of Entrepreneurship Journal, 25(3), 1-6.

Rotondo, G. (2020). Closing the Technology Skills Gap in Accounting Education: Making Excel Certification a Student Responsibility. Business Education Innovation Journal, 12(1), 30-37

Shamsudin, A., Pauzi, N.F M., Karim, M.S., Roslan, N., \& Ahmad, K. (2020). Utilising SATA in Measuring Students' Understanding of Financial Statements: A Survey among Non-Accounting Students. Jurnal Dinamika Akuntansi, 12(1), 24-33. DOI: https://doi.org/10.15294/jda.v12i1.24811

Shin, D., Kim, M., \& Kwak, Y. (2018). A Study on the standardization model of entrepreneurship support using ICT convergence. Journal of Advanced Information Technology and Convergence, 8(1), 13-22. http://dx.doi.org/10.14801/JAITC.2018.8.1.13

Sijtsma, K. (2009). On the use, the misuse, and the very limited usefulness of Cronbach's alpha. Psychometrika, 74(1), 107. DOI: 10.1007/S11336-008-9101-0

Sousa, M.J., Carmo, M., Gonçalves, A.C., Cruz, R., \& Martins, J.M. (2019). Creating knowledge and entrepreneurial capacity for HE students with digital education methodologies: Differences in the perceptions of students and entrepreneurs. Journal of Business Research, 94, 227-240. https://doi.org/10.1016/j.jbusres.2018.02.005

Sulaiman, M.M., Surajo, A.Z., \& Matinja, Z.I. (2020). Role of ICT for Entrepreneurship Development in Nigeria. KIU Interdisciplinary Journal of Humanities and Social Sciences, 1(2), 97-111.

Thottoli, M.M. (2020a). Knowledge and use of accounting software: evidence from Oman. Journal of Industry University Collaboration (ahead-of-print). Retrieved February 21, 2021 from https://www.emerald.com/insight/content/doi/10.1108/JIUC-04-2020-0005/full/html?utm_source=TrendMD\&utm_medium=cpc\&utm_campaign=Journal_of_Industry_-_University_Collaboration_TrendMD_1

Thottoli, M. M. (2020b). Impact of Accounting Software among SMEs Accountants in Oman. Retrieved February 21, 2021 from https://essuir.sumdu.edu.ua/handle/123456789/79294

Thottoli M.M. (2021), Impact of Information Communication Technology Competency Among Auditing Professionals. Accounting. Analysis. Auditing, 8(2), 38-47. https://doi.org/10.26794/2408-9303-2021-8-2-38-47

Thottoli, M.M., Thomas, K.V., \& Ahmed, E. R. (2019a). Qualitative Analysis on Information Communication Technology and Auditing Practices of Accounting Professionals. Journal of Information and Computational Science, 9(9). Retrieved February 21, 2021 from https://www.researchgate.net/profile/Essia_Ahmed/publication/337428182_Qualitative_Analysis_on_Information_Communication_Technology_and_Auditing_Practices_of_Accounting_Professionals/links/5dd6ebd8299bf10c5a26bc20/Qualitative-Analysis-on-Information-Communication-Technology-and-Auditing-Practices-of-Accounting-Professionals.pdf.

Thottoli, M.M., Thomas, K.V., \& Ahmed, E.R. (2019b). Adoption of audit software by audit firms: a qualitative study. Journal of Information and Computational Science, 9(9), 768-776.

Thottoli, M.M., Thomas, K. V., \& Ahmed, E R. (2019c). Examining the impact of informaiton communication technology on auditing professionals: a quantitative study. Journal of Advanced Research in Dynamical and Control Systems, 11(12), 476-488.

Thottoli, M.M., \& Thomas, K.V. (2020). Characteristics of information communication technology and audit practices: evidence from India. VINE Journal of Information and Knowledge Management Systems. Retrieved February 21, 2021 from https://doi.org/10.1108/VJIKMS-04-2020-0068

Vandenbosch, B. (1999). An empirical analysis of the association between the use of executive support systems and perceived organizational competitiveness. Accounting, Organizations and Society, 24(1), 77-92. https://doi.org/10.1016/S0361-3682(97)00064-0 
Venter, M., \& Swart, A. J. (2018). An integrated model for the continuous use intention of Microsoft Office simulation software. In 2018 IEEE Global Engineering Education Conference (EDUCON) (pp. 320-329). IEEE. DOI: 10.1109/EDUCON.2018.8363246

Verhoeven, J.C., Heerwegh, D., \& de Wit, K. (2020). Predicting ICT skills and ICT use of University students. Encyclopedia of Education and Information Technologies, 1286-1304. https://doi.org/10.1007/978-3-030-10576-1_226

Wu, Y.C.J., Wu, T., \& Li, Y. (2019). Impact of using classroom response systems on students' entrepreneurship learning experience. Computers in Human Behavior, 92, 634-645. https://doi.org/10.1016/j.chb.2017.08.013

Wu, Y.J., Yuan, C.H., \& Pan, C.I. (2018). Entrepreneurship education: an experimental study with information and communication technology. Sustainability, 10(3), 691. https://doi.org/10.3390/su10030691

Zheng, X. (2020). Analysis of Teaching Dilemma and Path Choice of Comprehensive Accounting Training Course Based on Computer-aided Technology. Journal of Physics: Conference Series, 1648 (3). https://doi.org/10.1088/1742-6596/1648/3/032123

\section{Author}

\section{Mohammed Muneerali Thottoli}

Master of Commerce, Madras University; Associate Company Secretary from ICSI (The Institute of Company Secretaries of India); Lecturer, Department of Accounting, College of Economics, Management and Information Systems, University of Nizwa, Nizwa, Ad Dakhiliyah, Oman. His research interests include accounting, auditing, ERP, and entrepreneurship.

Correspondence to: Mohammed Muneerali Thottoli, Lecturer, Department of Accounting, College of Economics, Management and Information Systems, University of Nizwa, Nizwa, Ad Dakhiliyah, Oman, P.O. Box 33, PC 616, e-mail: muneerali@unizwa.edu.om

ORCID (1) http://orcid.org/0000-0003-2195-7226

\section{Conflict of Interest}

The author declares that the research was conducted in the absence of any commercial or financial relationships that could be construed as a potential conflict of interest.

\section{Copyright and License}

This article is published under the terms of the Creative Commons Attribution - NoDerivs (CC BY-ND 4.0) License http://creativecommons.org/licenses/by-nd/4.0/ 
